\title{
The reemergence of the disappeared, the rope of remains and the forensic gaze
}

Collins, C. (2020). The reemergence of the disappeared, the rope of remains and the forensic gaze. Memory Studies, 13(3), 322-336. https://doi.org/10.1177/1750698020914016

Link to publication record in Ulster University Research Portal

\section{Published in:}

Memory Studies

Publication Status:

Published (in print/issue): 10/06/2020

DOI:

https://doi.org/10.1177/1750698020914016

\section{Document Version}

Author Accepted version

\section{General rights}

Copyright for the publications made accessible via Ulster University's Research Portal is retained by the author(s) and / or other copyright owners and it is a condition of accessing these publications that users recognise and abide by the legal requirements associated with these rights.

\section{Take down policy}

The Research Portal is Ulster University's institutional repository that provides access to Ulster's research outputs. Every effort has been made to ensure that content in the Research Portal does not infringe any person's rights, or applicable UK laws. If you discover content in the Research Portal that you believe breaches copyright or violates any law, please contact pure-support@ulster.ac.uk. 
First full draft. Author's version.

\section{The Reemergence of the Disappeared, the Role of Remains, and the 'Forensic Gaze'}

\section{ABSTRACT}

This paper explores what happens when the disappeared, reappear; considering how efforts to discovery and identify physical bodies are received, and what impact they have in exorcising the ghosts of the past. It discusses, following Gatti, the range of "catastrophes" that disappearance provokes, suggesting that reappearance, whether of living persons or human remains, can also lead to catastrophe. The piece argues that 'civic management' of disappearance creates a problematic new form of 'citizenship', paradoxically conferring special status that those disappeared were rarely afforded prior to their disappearance. Drawing on examples from Latin America and Northern Ireland, the piece considers how bodies without identities, like names without known destinies, disrupt social life, make claims on the living, and/or accuse perpetrators. It considers how forensic 'truth regimes' based on Western scientific principles sit alongside other ways of communing with the dead or disappeared.

\section{Keywords}

Disappearance

Latin America

Ghosts

Catastrophe

Identification

Forensics 
First full draft. Author's version.

\section{The Reemergence of the Disappeared, the Role of Remains, and the 'Forensic Gaze'}

when they ask you

to identify the body

and you see me

and a voice says

we killed him

the poor bastard died

he's dead,

when they tell you

that I am

completely absolutely definitely

dead

Don't believe them,

Don't believe them,

Don't believe them.

- Excerpt from Ariel Dorfman, Last Will and Testament

\section{Introduction}

Elsewhere in this edition, Paloma Aguilar and Marita Sturken discuss strategies for living with absence. They show how Spanish civil war families, and 9/11 families in the US, created new forms of private and public grieving in situations where death was acknowledged, but the bodies of the missing were hidden or obliterated. This brings us to the terrain explored by this paper: what happens when the disappeared, reappear? ${ }^{1}$ What can usher the missing back into the land of the living, or place them definitively on the rollcall of the dead? How credible are certification of death, identification of the abducted, or unearthing of remains, ${ }^{2}$ if done by the same forces who spirited away fathers, sons, sisters, and mothers; condemning communities to living with the shades of the absent? Is the reemergence of the disappeared, living or dead, easily assimilated, even by those who have long sought and demanded it? This paper explores whether and how those efforts to resolve or live with the ongoing consequences of disappearance that focus on the reappearance of bodies - whether alive or dead - acquire credibility, dispel doubt, and lay the ghosts of the past to rest. It underlines the particular difficulty of making authoritative truth pronouncements where, as Dorfman's verse suggests, belief, disbelief, and sometimes hope itself have long since been suspended.

The search for the disappeared is often - albeit misleadingly- equated with the search for human remains, an enterprise to which forensic techniques have become ever more central. ${ }^{3}$ Such

\footnotetext{
${ }^{1}$ The terms "disappeared", and "the disappeared" refer throughout to people intentionally and involuntarily taken from their communities of reference, in a context of political violence, not seen or credibly heard from since. The shading of meaning between this and other categories of missing person cannot be fully explored here. Sturken's assertion that 9/11 victims "have been disappeared" like the disappeared of Latin America would, however, fall outside this usage, since Sturken herself concedes that the intention to create indeterminacy was not to the fore. Spain is an intermediate case: while perpetrators arguably intended principally to kill, the issue of abducted children has recently come to the fore. Aguilar also shows that perpetrators actively concealed mass graves, prevented burial rituals, and denied relatives access to grave sites.

${ }^{2}$ The term 'remains' is disliked by some relatives and activists. However, unlike 'bodies', it can correctly be applied when only fragments or artefacts are found.

${ }^{3}$ The focus is misleading for various reasons. Where children were appropriated, the possibility of finding the disappeared alive remains open for decades to come. Sometimes, the more pressing challenge is not to find remains but to identify those whose location is already known. Remains can also be sought for purposes other
} 
techniques, often embraced in the search for certainty, are however only one of numerous competing and conflicting ways in which relatives, communities, society, science, judicial and administrative authorities seek to 'narrow the space of acceptable uncertainties' surrounding disappearance. ${ }^{4}$ Ambiguities surrounding the concept of disappearance, its aesthetics, and beliefs about whether and how the dead or disappeared continue to be within reach, can be inimical to certainty and closure. Drawing on examples from Latin American settings, plus Northern Ireland, this paper adheres to Gabriel Gatti's contention that disappearance creates both a "catastrophe of language" and "catastrophes of identity" (Gatti 2008, 2017). While we may do our best to "administer" (gestionar) the absence which gives rise to these catastrophes, definitive resolution exceeds our grasp: "Nothing falls into place, no: bodies come adrift from their identities; words are pried loose from things... identities without bodies, bodies without identities, and disrupted bloodlines are born". ${ }^{5}$

\section{What can we know, and how certainly can we know it?}

The irrevocability of things rent asunder in this way mires us in terrain where, since classic rationality is defied, we cannot aspire to make sense of everything. Gatti reminds us that the sociological enterprise "gets on very badly with things that it cannot apprehend". Both this assertion and the subtitle of his 2008 book - Narrativas posibles para una catástrofe de la identidad ${ }^{6}$ - are echoed in Avery Gordon's plea for a "post positivist" sociology that understands itself as taking part in "organising rituals" amounting to "situated storytelling" (Gordon, 2008). These are useful warnings for anyone who navigates the liminal terrain inhabited by the disappeared. We are left to conjure doubt and abjure uncertainty as best we can, faced with radically different kinds of truth claim: those based on Western scientific tropes; those which procure judicial truths; those which interpret visions and dreams as communication from ancestors, the absent, or the dead; those which treat ghosts as a metaphor, and those which firmly believe that they are real. ${ }^{7}$ Our own religious, cultural, personal and professional belief systems inescapably affect which we find most convincing. ${ }^{8}$

\section{Who is involved and addressed?}

This universe of intersecting epistemologies is clearly fertile terrain for haunting, whether in the senses advanced by Aguilar (where ghosts "express unmet collective needs", "promote moral action", and clamour for justice); or the more abstruse sense adopted by Gordon - who treats the ghost as "just the sign that a haunting is taking place", and haunting as "one way in which abusive systems of power make themselves known" (Gordon 2008: chap. 1). Reference to collective needs, justice, and abusive power bring the malignant intent of the perpetrator into the frame, suggesting the need for a reckoning. The mere restoration of bodies, or performance of the proper rituals, would not, in this

than identification, such as the amassing of prosecutorial evidence: see Stover and Shigekane, (2002); Tuller (2015) for the case of the former Yugoslavia.

${ }^{4}$ The paraphrase is of Michael Ignatieff's oft-cited maxim that post-transitional truthseeking can, at best,

"narrow the space of acceptable lies".

${ }^{5}$ Gatti: 2008, 12; my translation.

${ }^{6}$ Loosely translatable as "Possible Narratives in the Face of a Catastrophe of Identity".

${ }^{7}$ See discussion in Rojas-Pérez (2013) of intellectuals' deployment of 'ghosts' as an allegory, popular belief in them as "concrete historical entities", and relatives' experiences of exhumations provoking (benign) manifestations of the disappeared.

${ }^{8}$ An ongoing conversation between this author and Adam Rosenblatt, author of the excellent and sensitive book Digging for the Disappeared (2015), concerns the characterisation of 'international forensic experts'. Notwithstanding the undoubted common socialisation that this epistemic community of (usually) scientificallytrained experts shares, since each is 'from somewhere', each brings (pre)conceptions about death, the body, and the reverence due to human remains. Rosenblatt's preface, for example, references his family's Jewish heritage, while my own responses are conditioned by Catholic sensibilities, traditionally privileging the interment of the body in consecrated ground (see Navarro and Perez, 2007 on Guatemala). 
reading, suffice: communities of reference rarely act in isolation. ${ }^{9}$ Civic, scientific and/or judicial addressing or redressing of disappearance almost invariably requires authorities to act, or at least to acquiesce. Bureaucrats must certify; judges, pronounce, and experts, report, if disappearance is to be acknowledged, 'resolved', or at least, civically managed.

\section{When the Disappeared are Still Alive}

If mere restoration could suffice, right relationships might be restored, and the torn social fabric repaired, if the disappeared could only be found, and their rightful place in the order of things restored. ${ }^{10}$ This might be amongst the living, or in whatever place is considered the proper territory of the dead. The first of these is seemingly exemplified by Argentina's Abuelas, Grandmothers of the Plaza de Mayo, who continue to trace abducted children of the disappeared over forty years after they were taken. ${ }^{11}$ Novel scientific techniques, pioneered specifically for this task, continue to unite grandparents with their offspring. ${ }^{12}$ In the process, identities created by nurture and upbringing - the social identity of the abducted (former) child in their 'new' (experientially often their only) nuclear family - are treated as fraudulent, vitiated, and in need of replacement.

As Gatti points out, a potent underlying message here treats identity as conferred, primordially, by nature and by genetics (2008: 100). Resisting disappearance demands "reconstruction of that which the catastrophe [tried to] destroy" (ibid. p105), with new harm caused by the deliberate severing of existing affective bonds discounted against this gain. Restoration is thus portrayed as a 'moral action', in Aguilar's terminology: adopters become abductors, appropriators, candidates for moral opprobrium. Mere restoration is judged insufficient unless justice is also meted out to some perpetrator(s). The place of the missing middle generation - the birth parents - in this schema is indeterminate. Most often, they remain disappeared. Restoration and justice, even where achieved, are therefore incomplete. Adding insult to injury, restitution is not always welcome. Although the reappearance, alive, of the disappeared was, and still is, the principal demand of organised relatives' associations around Latin America, it trails a new set of potential catastrophes in its wake. It may, for example, afford definitive proof that the abductee's parents are no longer missing, but dead. ${ }^{13}$

Some abductees were brought up in military families, taught to fear or disdain political activists such as they now discover their own parents to have been. Others simply cannot reconcile themselves to their new circumstances, or forge new bonds - outcomes have included rejection, resentment, and in at least one case, suicide. New catastrophes of language can ensue: at a 2017 event organised by the state institution which leads Argentina's identification efforts, ${ }^{14}$ one recovered grandchild visibly struggled to refer to his adoptive father as his abductor ("el tipo que me apropió"), self-correcting

\footnotetext{
${ }^{9}$ Relatives are often treated as the principal community of reference of a disappeared person, but this can be problematic (Collins 2018). Here, "community of reference" denotes numerous circles of belonging - familial, geographical, political, cultural, religious, national - for which disappearance may represent a loss or affront. ${ }^{10}$ On unresolved disappearances and irregular mass graves as disruptive of communal wellbeing, see McAllister (2017); Klinkner (2008); Navarro García, Kernjak, Chalín et. al. (2007); and Stornaiuolo, Chauca, and Baca Soto (2007).

${ }^{11}$ Children either forcibly disappeared as infants, or born to women who had been pregnant when detained, subsequently "adopted" under false identities.

12 Penchaszadeh (2015). Penchaszadeh was one of three experts involved; alongside Eric Stover, and Cristián Orrego, to whose memory this paper is dedicated.

${ }^{13}$ One grandmother, interviewed in the documentary La Independencia Inconclusa, (Luis Vera, 2010) acknowledges "mixed feelings" after tracing her granddaughter: "that's when I knew for real that [my son and his wife] were never coming back".

${ }^{14}$ The Banco Nacional de Datos Genéticos.
} 
frequent lapses into more affectionate vocabulary. Hilario Bacca, known to Abuelas by his birth name of Federico Cagnola Pereyra, recently won a nine-year legal battle to keep the name of his adoptive parents. Bacca/ Cagnola is also one of various grandchildren who were forcibly identified, having refused voluntary testing. ${ }^{15}$ Re-appearance of the living, then, does not necessarily console - it involves unravelling as well as mending of the social fabric.

Attitudes to survivors provide equally uncomfortable examples of re-appearance without happy endings. It was not unusual in dictatorship-era Argentina, Chile or Uruguay for those released from clandestine detention to meet suspicion from political comrades, and relatives of those still disappeared. Grilled avidly for news - Who did you see? Who did you talk to? Where you were held? Who else was there? - survivors sometimes felt reduced to mere conduits of information about others (Duhalde and Rousseaux, 2015). The urgent desire to know outweighed consideration of survivors' needs, accentuating early onset of survivors' guilt. The (misplaced) belief that release could only mean that someone had broken under torture, confessed, given up names, or even agreed to inform after their release, moreover rendered survivors potentially suspect. A less rational 'contagion effect' also operated: the unspoken knowledge that former detainees had likely journeyed to the brink of hell left others unwilling to spend time in the company of the hollow-eyed, the visibly traumatised. Gatti's catastrophe of language operates here too: in Argentina, survivors often refer to themselves, or are referred to as, the "re-appeared" ("ex-detenidas/os desaparecidas/os"). ${ }^{16}$ The implication is that the interregnum during which they left the world of the known, the knowable, the locat-able, continues to define or indelibly mark them. These terms are little used in Chile, where 'survivor' or 'ex-political prisoner' are more current and only a handful of the disappeared have surfaced alive, although with equally arresting consequences. In 2008, a man listed by the Chilean Truth Commission as detaineddisappeared resurfaced alive and well in Argentina. He was disavowed by his family and relatives' associations alike, giving the unfortunate impression that his reappearance, far from being a cause for celebration, was disturbing and inconvenient. ${ }^{17}$

\section{When the Disappeared Need to Remain So}

What are the possible fates open to the disappeared who do not surface alive? One is to stay eternally trapped in some hinterland, a not-presence; a new, spectral, state of being, according to Lampasona (2013:8); a phantasm, according to Dürr (2017: 35). This third state between life and death even acquires its own citizenship, akin to the 'posthumous citizenship' that Aguilar, in this edition, describes as extended to exhumed Spanish civil war victims. That citizenship, she tells us, is constituted by acts of civic recognition and the bestowing of compensation entitlements on relatives. Analogous acts of recognition happen for Latin America's disappeared: many countries now officially commemorate the International Day of the Disappeared, extend reparations to relatives, and acknowledge the civic status of "absent by reason of enforced disappearance" or equivalent (Correa, s/d). Disappearance thereby risks becoming a normal, or at least a normed, state of affairs. Moon (2014) asks whether the dead now have human rights, answering in the affirmative insofar as we behave as if they do. In a similar vein, we might ask whether the trend toward institutionalised recognition and administration of disappearance, creates a unique and anomalous category of citizenship: phantoms with voting rights and national ID cards.

\footnotetext{
${ }^{15}$ Argentine courts have ordered, and a new law now specifically permits, compulsory DNA testing in such cases.

16 Park, 2014.

${ }^{17}$ Right wing commentators revived the long-debunked myth that the "disappeared" had actually left the country of their own volition. His family was meanwhile vilified for having received economic reparations based on his official disappeared status.
} 
First full draft. Author's version.

This absurdity arises because the status 'absent-because-disappeared' is yet another example of the stretching and tearing of concepts and language. The bureaucratic-rational state is generally keen to document and account for all its citizens. It must therefore decide how electoral rolls, civil registries, inheritance law, marriage regulations, etc., will address the absence of the disappeared, while neither denying their existence, nor consigning them to the farther shore of death at the stroke of a pen. These easy solutions have been denied to Latin American states largely by relatives' refusal to countenance them. In Northern Ireland, by contrast, administrative declarations of death - even without further revelation or discovery - have been embraced by families. ${ }^{18}$ The contrast has roots in the different role of the state in one, and the other, setting. In Latin America, state-perpetrated or sponsored enforced disappearance is often the main, or only, type of disappearance at issue. These are South America's detenidos-desaparecidos, who Gatti has called 'desaparecidos originarios'. ${ }^{19}$ Northern Ireland's conflict-related Disappeared are, by contrast, victims of nonstate, anti-state, armed actors. Since the state is not the perpetrator, it is seen as at least marginally credible, 'allowed' therefore to pursue non-judicial solutions not countenanced in other latitudes.

However codified or bureaucratically 'managed', the disappeared commune with a globally recognisable trope, often represented by placards, silhouettes, and photographs, brandished or worn as a lament, a challenge, and a demand ¿Dónde Están? ('Where Are They?'). This trope can be inhabited and appropriated, by relatives and perpetrators alike. For families and activists, the disappeared are a banner to rally under and a charge to be laid; evidence of the ongoing perfidy of perpetrators. Insistence on rejecting presumption of death also helps those who keep vigil to avoid the psychological burden of feeling that, in giving up hope, they somehow cause the figurative or actual death of the person for whom they search. ${ }^{20}$ For perpetrators, the disappeared may be an embarrassment or Achilles heel; but they can also be a bargaining chip, an ace in the hole, a valuable commodity traded for immunity, a reduced sentence, or a continued taste of power.

This powerplay is one of few universals in this field: anyone remotely familiar with on-the-ground searches for the disappeared will know that families, police, and prosecutors are regularly approached with offers to sell or trade information about the fate of individuals, or the location of remains. To reject such Faustian bargains out of hand can be attractive in its moral simplicity, but it condemns relatives, and others invested in the return of a loved one, to possibly eternal uncertainty. Tradeoffs that seemed unthinkable in the early years can become more tempting as lifecycles advance: parents and siblings face the possibility of dying without ever knowing the truth, or watching perpetrators take secrets to the grave. Relatives' associations in South America have generally refused to countenance concessions, rewards or incentives for information. They do not, however, speak for all families. Meanwhile, in Peru, and notably in Northern Ireland, laws allowing privileges for perpetratorinformants have been tolerated or even welcomed. ${ }^{21}$

\footnotetext{
${ }^{18}$ A former Northern Ireland Human Rights Commissioner proudly told this author how she had assisted relatives to press for a law permitting legal presumption of death for those still disappeared, largely regarded as anathema in Latin America.

${ }^{19}$ Or desaparecidos modélicos 'model disappeared', a Weberian ideal-type (Gatti 2011; Gatti et al 2019).

${ }^{20}$ This is a recognised psychological phenomenon, whereby acknowledging the fact or even the possibility of death, is experienced as having created that state of affairs. See Lira (2015:568).

${ }^{21}$ Laws allowing fully anonymised and confidential searches in the North and the Republic of Ireland appear genuinely condoned by the relatively small number of families searching for disappeared relatives. Sources: Dempster (2019); author meetings with some families, and the principal relevant NGO, 2016 and 2017.
} 
Rejection of bargains or administrative solutions reflects an understandable desire to insist on the possibility that the disappeared may be alive. It may, more controversially, amount to an investment in keeping the disappeared where they are, in limbo, "figure[s] not to be mourned because not dead, not alive, not even absent" (Gatti 2015:8, author's translation). When combined with a strong antiexhumation and anti-reparations stance, the embargo on compromise with perpetrators shades into the "vivos los queremos" paradigm associated with Argentina's Madres (Mothers) of the Plaza de Mayo. ${ }^{22}$ It takes someone close to, and highly sympathetic toward, their position to dare to suggest this amounts to "a commitment to not all of the disappeared, appearing", adding: "[in Argentina] we are all invested in the disappeared continuing to be disappeared. Take Maldonado - massive public reaction, completely deactivated when his body was found."23 The reference is to Santiago Maldonado, a young activist reported missing after an August 2017 protest. The case was taken up country-wide as an example of contemporaneous enforced disappearance, used to denounce the government. Weeks later, his remains were discovered submerged in a nearby river. Although the circumstances are still unclear, the huge momentum built up when the case was construed as a disappearance did indeed come to a halt almost overnight.

We see here that to be disappeared is to matter, to be made visible - paradoxically, given that the underlying intentions often include annihilation. By comparison, to 'simply' be deceased, or to (re)appear in a less than heroic manner - as above, for Chile - renders a person, and by extension their loved ones, more routine, more ordinary, less important. Those who disappear today along the migrant trail through Mexico, arguably attract more attention because of their disappearance, than in the previous course of their lives. In another example, the much-cited Ayotzinapa case is indelibly associated with the figure 43 . Often mistaken for the total number of victims, this number only includes the disappeared. Eight more victims, killed or injured, are almost never counted. The sense that disappearance demands particularly urgent attention, is surely justifiable in the early hours or days. ${ }^{24}$ As time passes, however, the distinction between the disappeared and the extrajudicially executed - a distinction perhaps uniquely firmly drawn in Chile - begins to look more like a victim hierarchy than a mere delineation of separate-but-equal tragedies. The settled nature of the distinction is visually evidenced in Santiago's General Cemetery, site of Chile's main memorial to victims of the dictatorship. Over three thousand names, inscribed on marble plaques, are grouped by category: the detained-disappeared to the left, the executed, on the right. Burial niches, similarly labelled, extend from each side. A literal reading might expect the left-hand array to stand empty in symbolic denunciation of the absence of the disappeared. In reality both sets of niches are partly filled with names, dates and photographs. Strictly speaking, the disappeared whose remains are subsequently discovered, or whose death is established with a robust degree of certainty, become, in Chilean terms, victims of political execution. In practice, this reclassification is never done.

The irony - and the renewed sense of language slipping from our grasp, insufficient to register unfolding layers of catastrophe - is not lost on relatives. Anyone closely involved in the return and reburial of formerly disappeared persons in Chile will have heard variants of the following: "I don't know who I am any more.... For 40 years, I've been the mother of a disappeared [person]. Now I've got what we all want... How can I show my face at the [Relatives] Association now? How will the rest

\footnotetext{
22 The full rallying cry is "they were taken alive, we want them back alive". Rosenblatt (2017).

${ }^{23}$ Closed group interview with Argentine organisations connected to search, Buenos Aires, 10 May 2018.

${ }^{24}$ Records of Chilean relatives' associations' early meetings demonstrate this sense of urgency: "we have to rescue them from detention.... This is a race against time." (Lira 2015: 556, my translation).
} 
feel? But I can't go to the others either, they're not my people!". ${ }^{25}$ This vignette points to at least one vital issue, not fully explored here: the need to attend to the post-return stage of longstanding disappearances. Relatives must carve out yet another life project, often at an advanced age. Those accustomed to 'conversing' every day with their missing loved one report that suddenly they hear no reply, only silence. Those who kept homes untouched, awaiting the desired return, feel unequal to the task of disposing of the person's clothing and possessions. Even those who say they always accepted that their loved one was dead, can experience this moment as the end of all their secret hopes. The difficulty of even contemplating this denouement may make it perversely desirable that not everyone is found; or at least, that the potency of what disappearance wrought - unrightable wrongs, immeasurable harm - somehow continues to be recognised, even in the hypothetical case where all the disappeared are returned to their families. ${ }^{26}$

\section{The Outer Edges of Disappearance: When Does it End? What Comes Next?}

The uneven treatment of the disappeared, as distinct from the dead, and the difficult transition from one state to the next, has a quite particular expression in Colombia. Here, the absence not of bodies, but of a name, seems to mark the distinction. If the still-disappeared of Chile are Gatti's "identities without a body", the 'NN' of Puerto Berríos are his "bodies without identity". The documentary film "Réquiem NN" (dir. Juan Manuel Echavarría, 2013) depicts the inhabitants of the small town of Puerto Berríos, who 'adopt' the corpses of unknown victims of violence carried to the town by the local river. Rather than interring these remains in a communal grave, under the inscription NN (name unknown) - as would be usual in much of Latin America - townspeople place them in individual niches, as for a family member. The niches are visited and flowers, prayers, and rites are offered, on significant dates such as the Catholic feast day of All Souls. These practices treat the unknown deceased as in need of care, but also as possessors of agency and power. Traditional Catholic doctrine holds that the 'souls of the faithful departed' may pass through purgatory, a place of purification, before being admitted to God's presence. Prayer from the living can speed this soul's passage to heaven; at the same time, souls in purgatory can intercede with God on behalf of the living. ${ }^{27}$ Popular religiosity in Latin America also often reveres victims of unexpected or violent death, promising mandas (acts of sacrifice or selfdenial) in return for favours requested, a kind of transactional devotion otherwise reserved for saints and the Virgin Mary.

The ' $N N^{\prime}$ ' bodies, assumed to have met with a bad, untimely, or violent death, are entreated to help the living, presupposing a continued capacity to be communicated with, and to act in the material world. The question of whether there is also an element of placation, deflecting potentially malign influence, is left open. It is however salutary to ask what happens if and when identities become known. If an abandoned NN were to be identified and reclaimed, would the aura of quasi-sacrality surrounding them, dissipate? Would everything change if the body were removed, reburied in the

\footnotetext{
${ }^{25}$ This composite discourse accurately tracks a number of real conversations with this author. 'Others' refers to the Association of Relatives of Victims of Political Execution. The two groups separated quite early, facing different needs, priorities and challenges. The sheer length of subsequent activism means people are strongly socialised into whichever affective community first welcomed them.

${ }^{26}$ This horizon, seemingly fantastical in Latin American settings where thousands were disappeared, is quite feasible in Northern Ireland, where only three people remain to be located. The impulse I attempt to describe is the desire not to allow recovery and restitution of all the disappeared to diminish the enormity of what was done.

${ }^{27}$ In its timing and content, All Souls represents the usurpation of pre-Colombian Day of the Dead traditions. These, like the Celtic festival of Samhain, invite people to communicate and commune with departed ancestors, when the veil between the worlds of the living and the dead is considered to be at its thinnest.
} 
family plot in another town or village, with no-one aware of its brief exposure to special status? It might transpire that remains buried as NN belonged to a trafficker, paramilitary, or other perpetrator of violence. Would this quench the mourners' impetus, or does the spiritual power conferred by a mala muerte persist irrespective of the moral character of the dead? One might also ask in what sense, if any, ' $\mathrm{NN}$ ' remains are 'disappeared'. If they are so considered, disappearance has shed all necessary association with physical invisibility, non-tangibility, not-there-ness. But can we assert that the person to whom the remains belong, ceases to be a victim of disappearance solely because their still-unidentified body has been found? At least while no-one knows to whom a recovered body "really" belonged in life, surely that missing human being is still being actively subjected to the ignominy, of negation of their personhood. If and when body and identity are successfully reunited, what is the effect on the trope of disappeared-ness? A change of status, to 'mere' victim of homicide or extrajudicial execution, does not wipe out the additional crime committed. ${ }^{28}$

Communities may be well aware who has been killed, and even know where the dead are buried. If these victims remain disappeared at all, in any meaningful sense, it is in the eyes of the state. El Mozote in El Salvador, Putis in highland Peru, and post-Civil War Spain offer examples. It would be hard to argue exact equivalence between the situation of these victims and that of people spirited away by state or other forces, of whom nothing further is known. The Guatemalan nonstate forensic team FAFG, for example, distinguishes among four categories of disappearance: the internally displaced person, who may succumb to hypothermia or starvation rather than bullets or machetes; people caught up in 'scorched earth' military raids on areas associated with guerrillas; victims of assassination, and victims of enforced disappearance. ${ }^{29}$ Such differentiation, like the use of qualifiers such as 'quasi' or 'authentic', ${ }^{30}$ is controversial, as it may lend itself to the prioritisation of one or other type of case. Where death is strongly presumed, and remains were inhumed close to the site of disappearance, the level of remaining uncertainty about the fate of individuals may admittedly be lesser. Nonetheless, families must still negotiate extremely daunting practical problems, while communal, familial, spiritual or psychological distress can arise from proximity to irregular gravesites containing human remains "out of place" (Colombo, 2017). ${ }^{31}$

\section{The Role of Remains: an End to Catastrophe, or the Emergence of New Conundrums?}

Even when remains can be located, it does not follow that exhumation, individuation, and scientific identification according to the Western canon, are desirable. In Peru, already-located mass graves became an easy option for state prosecutors with targets to meet, and gravesites were intervened directly counter to the expressed desires of some families. Years later, some remains removed in this way have still not been identified or returned. This fact, widely known, causes new kinds and levels of distress. As a result, communities grow reluctant to provide any information to national authorities, or seek local-level solutions. These include the 'officialisation' of irregular mass burial sites through municipal certification, or the performance of civic or religious rituals that transform the technically disappeared into the officially deceased. This can trigger a recognisably distinct next phase of life for

\footnotetext{
${ }^{28}$ The point is not mere casuistry: in late 2018, a jailed perpetrator in Chile appealed his sentence for enforced disappearance, arguing that the subsequent discovery of remains entitled him to the lower tariff applicable to homicide.

${ }^{29}$ José Samuel Suasnavar, presentation to ALAF conference, Sao Paulo, Brazil, 25 October 2017.

${ }^{30}$ Macciuici (s/d).

${ }^{31}$ The 2017 play The Ferryman depicts a Northern Irish family torn apart anew by the appearance of the remains of a former IRA volunteer 'disappeared' by his own comrades. A young family member asks plaintively: “Where has his soul been all this time?” (Butterworth 2017).
} 
First full draft. Author's version.

families, allowing practical as well as affective matters to be resolved (certification of death, transfers of property or inheritance, the transition from wife to widow, husband to widower, etc.)

The uncovering or officialization of mass graves in Peru, like the discovery in Colombia of remains bereft of identities, are the logical correlate of unresolved disappearances. They may also be, in a more poetic sense, their objective correlative, resolving a 'civic anomaly' but evoking the full horror of disappearance for onlookers, searchers, and family members. Sturken, in this edition, quotes Gordon (op.cit.) to the effect that ghosts appear when the trouble they represent ceases to be repressed. If this is so, it is not just the initiation of disappearance that could give rise to 'haunting'. The emergence into public consciousness of the practice, and/or the (literal) unearthing of evidence of it, would provide additional junctures at which the veil between the visible and invisible worlds could wear thin. Thus, for Chile, the 1978 appearance of the first bodies of the disappeared, or the first post-transitional uncovering of a mass grave, in 1990, might create or release new spectres. Identified remains can therefore be a source of certainty about death - Hamlet's 'consummation devoutly to be wished' - without signifying the definitive exorcising of spirits. Remains may also become a call to action. According to Keenan and Weizman, "human remains are the kind of object from which the trace of the subject cannot be fully removed" (2012:13). ${ }^{32}$ Meloni treats the reappeared body as a political actor: "the irruptive, tempestuous spectre [brought forth by] remains that come to light, bringing with them testimony of a crime and the clamour for justice" (Meloni 2019:17, author's translation). Ferrándiz (2011) also discusses how exhumed bodies affect the social field, describing the necessary collective soulsearching as a 'social autopsy'. These new types of demand, made on the living by the previously absent or unknown dead, return us to the question of justice. The issue of what changes when we come to know exactly who lies in an ' $N N^{\prime}$ ' niche or unmarked grave, meanwhile raises the question of identification. All involve consideration of the role and status of science, and of the forensic expert.

\section{Forensics: the New 'Dismal Science'?}

A strict definition of "forensic" denotes science in connection or dialogue with law. Notwithstanding, common usage, plus a deliberate loosening of the association between forensic work and formal prosecution, have placed clear blue water between recovery and identification, and judicial forums. It is correspondingly increasingly commonplace to distinguish between 'humanitarian' and 'judicial' modes of search. ${ }^{33}$ The former is characterised as centred on the finding and restoration of identity or remains; the latter, on providing prosecutorial evidence. Forensic specialists - anthropologists, archaeologists, geneticists - are often central to both. Whether working for the state or quite deliberately independently of it, forensics practised for human rights-related ends has become a subfield in its own right. The ongoing reality of disappearance has called into being a new genus of human rights professional. ${ }^{34}$

Forensic practitioners and the apparent certainty they bring are often welcomed, and sometimes lionised, by relatives' associations. Where the state is absent, deficient, complicit, or directly culpable,

\footnotetext{
32 Perpetrators of enforced disappearance currently on trial in Chile disagree: their lawyers adduce in oral argument that illegal burial of remains is not a crime against humanity, because what is being disposed of is a mere object, not a human being.

${ }^{33}$ See Rosenblatt (2019) for a critical account of this somewhat tendentious binary.

${ }^{34}$ Rosenblatt (2015).
} 
independent forensic teams, in particular, may be seen as reliable, authoritative, allies. ${ }^{35}$ Physical and affective proximity is also created by the nature of forensic anthropological work. If there is to be an exhumation, for example, forensic experts, almost uniquely among the relevant professions, cannot operate from a pristine office in the capital city. They will be down in the dust and dirt alongside relatives and other searchers. José Samuel Suasnavar, of Guatemala's FAFG, believes this gives forensic teams unique insights: "we can come to know more about what relatives and communities really need. The people see you out in the field with them, sweating under the sun, working hard with your hands, as they do... it creates confidence, they open up (...) the forensic people are often the ones relatives really trust". ${ }^{36}$ This privileged position inevitably creates power asymmetries, as do other professional interventions in search. The impulse to gatekeep between relatives - rightly or wrongly perceived as disempowered or disadvantaged - and authorities, the media, etc., plus forensic practitioners' possession of abstruse types of knowledge, can construct them as an almost 'priestly caste'. Certainly, few other actors understand the scientific procedures that underlie their pronouncements well enough to corroborate or challenge them. This makes accountability an important, sometimes thorny, question. Nonstate forensic actors are sometimes less keen to accept peer review, than to insist that state services and laboratories lay their own practices open to scrutiny. Some can be tempted to stray beyond the bounds of their specialism, with results that can appear startling to the outsider, including improvised graveside rituals that mimic mass executions. ${ }^{37}$

It is striking that forensic experts should acquire such a pivotal role in performing reappearance, and enjoy such closeness with relatives and searchers, given that - with the sole exception of those forensic geneticists who identify the living - their work paves the path to the cemetery. While identification of remains may bestow certainty, this is the negative certainty of a death sentence. Resistance to this outcome is the reason forensic work was initially rejected by Argentina's Madres, ${ }^{38}$ and may explain why expert identification is not always accepted or believed. Dreams, clothing, and other artefacts - sometimes taken as proof of death, sometimes, proof of life - may be afforded greater credence by relatives than identification based on bones or bone fragments, indistinguishable one from another to the naked eye. ${ }^{39}$ Documented cases of error, some avoidable, also undermine the pretensions of science-based identifications to constitute the last word. ${ }^{40}$

In performing identification, not all forensic personnel are 'scientist' in the sense decried by Moon (2013: 151). Zarankin and Salerno suggest, indeed, that Latin American forensic anthropology is uniquely socially and politically aware, while Luis Fondebrider, well-known founder member of the legendary Argentine EAAF, has asserted that "before being a forensic anthropologist one is an

\footnotetext{
${ }^{35} \mathrm{Viz}$. the role of the Argentine forensic anthropology team, EAAF, and of the forensic architecture team led by Eyal Weizman, in debunking official versions of events in the Ayotzinapa investigation. See InterAmerican Commission on Human Rights (2018); and www.forensic-architecture.org

${ }^{36}$ Jose Samuel Suasnavar, FAFG, author interview, Sao Paulo, 25 October 2017.

${ }^{37}$ Footage of a recent Spanish exhumation shows young volunteers instructed to lie with their eyes closed in an excavated (empty) mass grave, while the expert in charge of the dig mimics the sound of bullets. Relatives look on. On file with the author.

${ }^{38}$ Due to a continuing insistence on reappearance alive, plus the view that recovery of remains would deactivate or depoliticise families. The sea change in relations, at least with the nonstate EAAF, is demonstrated by the fact that EAAF currently operate from premises ceded to them by Madres (Calvo, 2019). 39 Ugaz (2015); Fernández Muñoz and Congram (2016); Baby and Nérard (2017).

${ }^{40}$ Chile's 'Patio 29' is perhaps unfairly emblematic of such 'errors', which sometimes simply reflect the state of development of available techniques.
} 
anthropologist... a holistic, more comprehensive approach than other scientific disciplines". ${ }^{41}$ Many Latin American forensic teams, particularly nonstate ones, include historians, memory specialists, and even relatives among their staff, and do not necessarily subscribe to a narrowly biologist approach to identity. The idea not only that all identification is social, but that disappearance must be addressed in all its dimensions, including its power to accentuate inequality and poverty in affected communities, is for instance particularly associated with EPAF Peru, and founder José Pablo Bayrabar. Nonetheless, definitive identification of remains, whether social and/or biological, explodes the myth of return, thereby extinguishing the flame of hope. One thing that scientists and their teams can nonetheless supply, apart from grief, is the possibility of justice. If their findings meet the credibility threshold needed to be transformed into judicial truth, consequences may follow, whether against perpetrators (criminal prosecution), or in favour of families (civil claimmaking or reparations).

\section{The "Forensic Turn": Physical Objects and Expert Witnessing in the Justice Forum}

In a 2012 book and exhibition entitled 'Mengele's Skull', Thomas Keenan and Eyal Weizman suggest that the international scientific enterprise that in 1985 identified a set of human remains as those of hunted Nazi war criminal Josef Mengele marked a "forensic turn" in war crime prosecutions and atrocity investigation. This 'turn', they claim, displaced the document and the witness in favour of artefacts and other supposedly 'hard' evidence. Such evidence is seen as objective and unmediated, more suited to juridical certainty. Scientific analysis is considered capable, at the very least, of delineating a set of established facts, for which any truth claim with pretensions to validity would need to account. The book however contends that any number of "aesthetic, political, and ethical complications (...) emerge with the introduction of the thing in war crimes trials" (Keenan and Weizman 2012: 13). This is perhaps particularly so when the "thing" in question is no common or garden manmade artefact or inanimate object, but is of human origin. Remains, that very particular subtype of the reappeared, therefore take centre stage where disappearance and/or mass killing are on trial.

Weizman asserts elsewhere that "bones are a special order of things, still haunted by the subject" (2017:83). His 2012 book with Keenan meanwhile includes a telling description, complete with photograph of the celebrated forensic expert Clyde Snow testifying at the trial of the Argentine military junta in $1985 .{ }^{42}$ The lights are dimmed, a screen is unfurled, and Snow, presiding over the magic lantern, conjures truth claims from and about images of human remains. Snow liked to claim that bones can speak. Of course, they cannot: unlike living witnesses, they require experts, conjurers, and shamans to speak on their behalf. If the object - a bone - is to be treated, following Weizman, as the vessel of some ghostly subject, some medium is needed to transmit what (it is claimed) is being said. The contention that the forensic turn displaces the witness thus needs to be qualified. More accurately, such a turn deauthorises one kind of witness - the lay witness, the eyewitness, the survivor - in favour of the expert witness, the technician, the scientist. The guarantor of credibility is almost inverted: reliability is predicated not on presence and direct involvement, but on a certain expectation of distance, and disinterestedness. The forensic expert is expected to rise above rumour and partiality, testifying only to the outcomes of rigorous application of conventionally accepted scientific method. In the process, he or she displaces not only the witness but also the judge and/or jury, previously unassailable as trier(s) of both fact and law. 'Facticity' becomes the province of the scientist, in conversation with and about human remains, delivering a type of testimony that few non-scientists

\footnotetext{
${ }^{41}$ Fondebrider (2015), commenting on a hypothetical situation in which relatives, having experienced a dream in which the disappeared person reveals the circumstances of their death, feel no need for forensic confirmation.

${ }^{42}$ Keenan and Weizman, op. cit., p.71.
} 
fully understand. Subjectivity and agency have not, however, been eliminated from the justice process: they have simply been relocated into the person of the expert. For this reason, amongst others, Keenan and Weizman (2012:12) indicate that the forensic turn is "not simply one in which the solid object provides a stable and fixed alternative to human uncertainties, ambiguities, and anxieties.". Nonetheless, in respect of the 'posthumous citizenship' discussed by Aguilar, or the nascent citizenship of the disappeared posited by this paper, what matters is the standard applied by civic authorities, who determine who is given up for dead, who is treated as still living, and who remains in between. For these effects, a 'scientistic' understanding of identification, with mitochondrial DNA as the gold standard, currently predominates.

\section{Concluding remarks}

We have seen how one category of the disappeared - those deliberately removed from private and public space by malevolent agency - are paradoxically made newly visible, or visible in a different way, by attempted obliteration. Gatti's "desaparecidos originarios" have become ausencias presentes (present absences). Promises are made to and extracted from them, placards are carried, votive candles are lit, and enormous efforts are made to conjoin names with bodies, or remains with identities. The disappeared are treated as the most tragic or dramatic personification of victimhood not only vanquished but annihilated, conjured out of being - but also somehow as residually powerful, even threatening. The unnamed dead, and the names of those long unseen, are treated as presences or absences to be placated, succoured, or avenged: beings capable of causing disruption to the ongoing life of the community. A moral burden to remember but also to search and "lay to rest" is often deduced, and this burden is more often or more visibly placed on the shoulders of survivors and relatives, rather than perpetrators. At the same time, the power of the disappeared to clamour, to accuse and to disturb has become global. By virtue of having been disappeared - rather than "only" killed or injured - the disappeared become an object of international concern, spurring to scientific innovation and the emergence of a new branch of the forensic arts. This visibility can far exceed the prior, or subsequent, capacity of those same individuals to attract attention in life or in (duly administered) death; overshadowing, in turn, the attention paid to other categories of victimhood.

The liminality of the disappeared, which has its own agency and may even confer a kind of citizenship, is dispelled or at least transmuted in various possible ways. When and by what act the fact of death is acknowledged, accepted, and given meaning depends on whose gaze or perception is being considered: death, like disappearance and like existence itself, is socially constructed. The frequency with which disappearance involves both political intent and state perpetration moreover amplifies a credibility gap when it comes to official truth claims or actions that attempt to address the restless shades or spirits of the disappeared. The radical doubt that festers alongside the radical uncertainty intrinsic to disappearance helped to fuel a turn toward physical sciences and sciences of the body. The hope was perhaps that the forensic procedures or interventions could succeed where other social processes failed, garnering universal adherence to irrefutable 'moments of truth'. Thus, whether in the agora (civic forum), the private forum of the family, or the normed performative space of the courtroom, those designated as 'expert' producers of truth are deputed to commune with the world of the disappeared. Like explorers mapping new terrain for possible conquest, they bring back news. This news, if heeded, re-establishes the social existence of two types of physical body - the still-living, and the definitively dead. The truth regime constituted by forensics however proves, on closer examination, to contain its own contradictions and subjectivities. It therefore takes its place alongside many alternative ways of conjuring with disappearance. The shades of the still-disappeared refuse to be exorcized, continuing to exert a power that is aesthetic, political, spiritual, and sometimes atavistic. 
First full draft. Author's version.

\section{Reference list}

Baby $S$ and Nérard F (2017). Objects from the Missing: Exhumations and uses of the material traces of mass violence. In Baby and Nérard (eds.) Material Traces of Mass Death: The Exhumed Object. Les Cahiers Sirice no. 19, Paris: UMR Sirice, pp. 5-20

Banco Nacional de Datos Genéticos (2017) Una Pregunta: 30 años: Memoria Escrita del Banco Nacional de Datos Genéticos. Buenos Aires: Ministerio Secretaria General de la Presidencia.

Butterworth J (2017) The Ferryman London: Nick Hern Books.

Calvo P (2019) Desaparecidos de la dictadura: 600 cuerpos que esperan. Clarin! Revista VIVA 22 March

Colombo P (2017) Espacios de desaparición. Vivir e imaginar los lugares de la violencia estatal (Tucumán, 1975-1983). Buenos Aires: Miño y Dávila.

Correa C (s/d) Left in the Limbo: addressing the legal consequences of disappearances. Paper on file with author.

Dempster L (2019) Transitional Justice and the 'Disappeared' of Northern Ireland: Silence, Memory, and the Construction of the Past. Glasshouse/ Routledge.

Dürr C (2017). Memorias incómodas. El dispositivo de la desaparición y el testimonio de los sobrevivientes de los Centros Clandestinos de Detención, Tortura y Exterminio. Temperley: Tren en Movimiento.

Duhalde EL and Rousseaux F (2015) El ex detenido-desaparecido como testigo de los juicios por crímenes de lesa humanidad. Buenos Aires: Fundación Eduardo Luis Duhalde

Fernández Muñoz, A and Congram, D (2016) The Evidentiary Value of Cultural Objects from Mass graves: Methods of Analysis, Interpretation, and Limitations. In Congram, ed. Missing Persons: Multidisciplinary Perspectives on the Disappeared. Toronto: Canadian Scholars' Press, pp.269-287

Fondebrider $L$ (2015). Forensic Anthropology and the Investigation of Political Violence: Notes from the Field. Chapter 2 of Crossland Z and Joyce R (eds.) Disturbing Bodies. Perspectives on Forensic Anthropology. Santa Fe: School for Advanced Research Press

Gatti G (2008) El detenido-desaparecido. Narrativas posibles para una catástrofe de la identidad. Montevideo: Trilce.

Gatti G (2011) De un continente al otro: el desaparecido transnacional, la cultura humanitaria y las víctimas totales en tiempos de guerra global. Política y Sociedad 48(3): 519-536.

Gatti G (ed.) (2017) Desapariciones. Usos locales, circulaciones globales. Bogota: Siglo del Hombre/ Universidad de los Andes.

Gatti G Irazuzta, I and Martínez, M (2019) Introducción. La desaparición forzada de personas: circulación transnacional y usos sociales de una categoría de los derechos humanos. Oñati Socio-legal Series 9(2): 145-154.

Gordon A (2008) Ghostly Matters: Haunting and the Sociological Imagination. Minneapolis: University of Minnesota Press. 
First full draft. Author's version.

InterAmerican Commission on Human Rights (2018) Situation Report: Special Followup Mechanism to the Ayotzinapa Case of the IACHR. Report, Organisation of American States, OEA/Ser.L/V/II. Doc. 82, 5 June 2018.

Keenan T and Weizman E (2012) Mengele's Skull: The Advent of a Forensic Aesthetics. London and Frankfurt: Sternberg/Portikus.

Klinkner M (2008) Forensic Science for Cambodian Justice. International Journal of Transitional Justice (2): 242

Lampasona J (2013). Desaparición forzada en Argentina: entre la desaparición y la sobrevida. 0 sobre la 'regla' y la 'excepción' en el despliegue de la tecnología de poder genocida. Aletheia, 3(6): 120

Lira E (2015) Chile, Desaparición Forzada: 1973 a 2015. In Giusti M, Gútierrez G and Salmon E (eds.) La Verdad Nos Hace Libres. Lima: Pontificia Universidad Católica del Perú, pp. 549-573

McAllister C (2017) What Are the Dead Made of? Exhumations and the Materiality of Indigenous Social Worlds in Post-Genocide Guatemala. Material Religion 13(4): 521-523

Macciuici R (s/d) El Concepto de Desaparecido en España y Argentina: nuevas consideraciones. Paper available from www.academia.edu or on file with the author.

Meloni González C (2019). Cadáveres insumisos: hacia una ética del asedio y de la hospitalidad. Papeles del CEIC, vol. 2019/1, papel 205: 1-21.

Moon C (2013) Interpreters of the Dead: Forensic Knowledge, Human Remains, and the Politics of the Past. Social and Legal Studies 22(2): pp 149-169

Moon C (2014) Human Rights, Human Remains: forensic humanitarianism and the human rights of the dead. International Social Science Journal 65(215-16): 49-63

Navarro García S, Kernjak F, Chalín, Y et al. (2007) Veinte años de exhumaciones: un largo proceso de aprendizaje. In Pérez Sales, P and Navarro García S (eds.), Resistencias contra el olvido: Trabajo psicosocial en procesos de exhumaciones. Barcelona: Gedisa, pp. 61-91.

Park R (2014) The Reappeared: Argentine Former Political Prisoners. New Brunswick, NJ: Rutgers University Press.

Penchaszadeh V (2015). Ethical, Legal and Social Issues in restoring Genetic Identity after Forced Disappearance and Suppression of Identity in Argentina. Journal of Community Genetics. Jul; 6(3): 207-213.

Rojas-Pérez I (2013) Inhabiting Unfinished Pasts: Law, Transitional Justice and Mourning in Postwar Peru. Humanity, Spring: 149-170, (esp. p.160 and fn.10).

Rosenblatt A (2015) Digging for the Disappeared: Forensic Science after Atrocity. Stanford, CA: Stanford University Press

Rosenblatt A (2017) Aparición con vida: Disappearance and the Politics of the Counterfactual, from Argentina to Ayotzinapa. Conference paper summarised in: Robledo, C Informe-Relatoría "La política de la ausencia": Desafíos forenses, humanitarios y jurídicas en la recuperación e identificación de las y los desaparecidos. e-publication, Santiago: Observatorio DDHH/ Universidad Diego Portales, available via www.derechoshumanos.udp.cl 
First full draft. Author's version.

Rosenblatt A (2019) The Danger of a Single Story about Forensic Humanitarianism Journal of Forensic and Legal Medicine 61 (February): 75-77.

Stornaiuolo M, Chauca RL and Baca Soto N (2007). Acompañamiento psicosocial en procesos de investigación antropológica forense en Perú. In P. Pérez Sales \& S. Navarro García (Eds.), Resistencias contra el olvido: Trabajo psicosocial en procesos de exhumaciones. Barcelona: Gedisa, pp.93-112.

Stover E and Shigekane R (2002). The Missing in the Aftermath of War: When Do the Needs of Victims' Families and International War Crimes Tribunals Clash? International Review of the Red Cross 84 (484)

Tuller $\mathrm{H}$ (2015) Identification versus prosecution: is it that simple, and where should the archaeologist stand? In: Crossland, Z, and Joyce RA (eds.) Disturbing Bodies: Perspectives on Forensic Anthropology. School for Advanced Research Press; pp. 85-101.

Ugaz P (2015) Chínkaqkuna: los que se perdieron. Lima: Colectivo Desvela, pp. 41-42

Zarankin A and Salerno M (2008). Después de la tormenta. Arqueología de la represión en América Latina'. Complutum 19(2). 